\title{
Cytological Studies on Bolbitis quoyana (Gaud.) Ching
}

\author{
K. V. Bharanandan \\ Department of Botany, University of Kerala, \\ Kariavattom, Trivandrum, 695 581, India
}

Accepted October 17, 1983

Bolbitis quoyana is a tropical leptosporangiate fern, belonging to the family Aspidiacease (Copeland 1947). A preliminary report on the somatic chromosome number $(2 n=123)$ of this species was made earlier by the present author (Bhavanandan 1968). A perusal of cytological literature on the genus Bolbitis reveals that species of the genus studied so far from different geographical regions (Manton 1954 1959, Manton and Sledge 1954, Walker 1966) including India (Abraham et al. 1962) are either diploids $(n=41)$ or tetraploids $(n=82)$ except $B$. quoyana which is a triploid based on $x=41$. A detailed meiotic and karyomorphological study of this triploid species has been made with a view to shed light on the nature and origin of this taxon.

\section{Material and methods}

Material for the present study was collected from the Public Gardens, Trivandrum. Young sporophylls were fixed in 3:1 ethyl alcohol and acetic acid for meiotic chromosome studies. The somatic chromosome studies were made from root tip cells. For this, actively growing root tips were collected in water and kept them in the refrigerator at about $4^{\circ} \mathrm{C}$ for overnight prior to fixation in $3: 1$ ethyl alcohol and acetic acid. The acetocarmine squash technique was followed for chromosome studies. Addition of a few drops of ferric ammonium sulphate to the fixative increased the stainability of the chromosomes. The systems of Levan et al. (1964) and of Stebbins (1958) were followed for karyotype analysis. TF\% has been calculated as given by Huziwara (1962).

\section{Results}

The spore mother cells showed 41 bivalents and 41 univalents at metaphase I (Fig. 1). The subsequent stages of divisions were irregular. The univalents were scattered throughout the cytoplasm. Those univalents which were not included in any of the poles formed laggards at anaphase I (Fig. 2) and later they organized to form micronuclei of varying sizes at telophase I (Fig. 3). The laggards and micronuclei were observed at anaphase II and telophase II respectively (Fig. 4). Micronuclei were also seen in the tetrads (Fig. 5). This meiotic irregularity resulted in almost total spore sterility.

The somatic chromosome studies were carried out from the root tip cells, which showed 123 chromosomes at metaphase (Fig. 6). A detailed karyotype analysis 
of chromosomes was made, and the data shown in Table 1. The chromosomes were all medium sized and the length varied from $3.5 \mathrm{~m} \mu$ to $7 \mathrm{~m} \mu$.

From the data obtained from the detailed karyotype analysis of the somatic

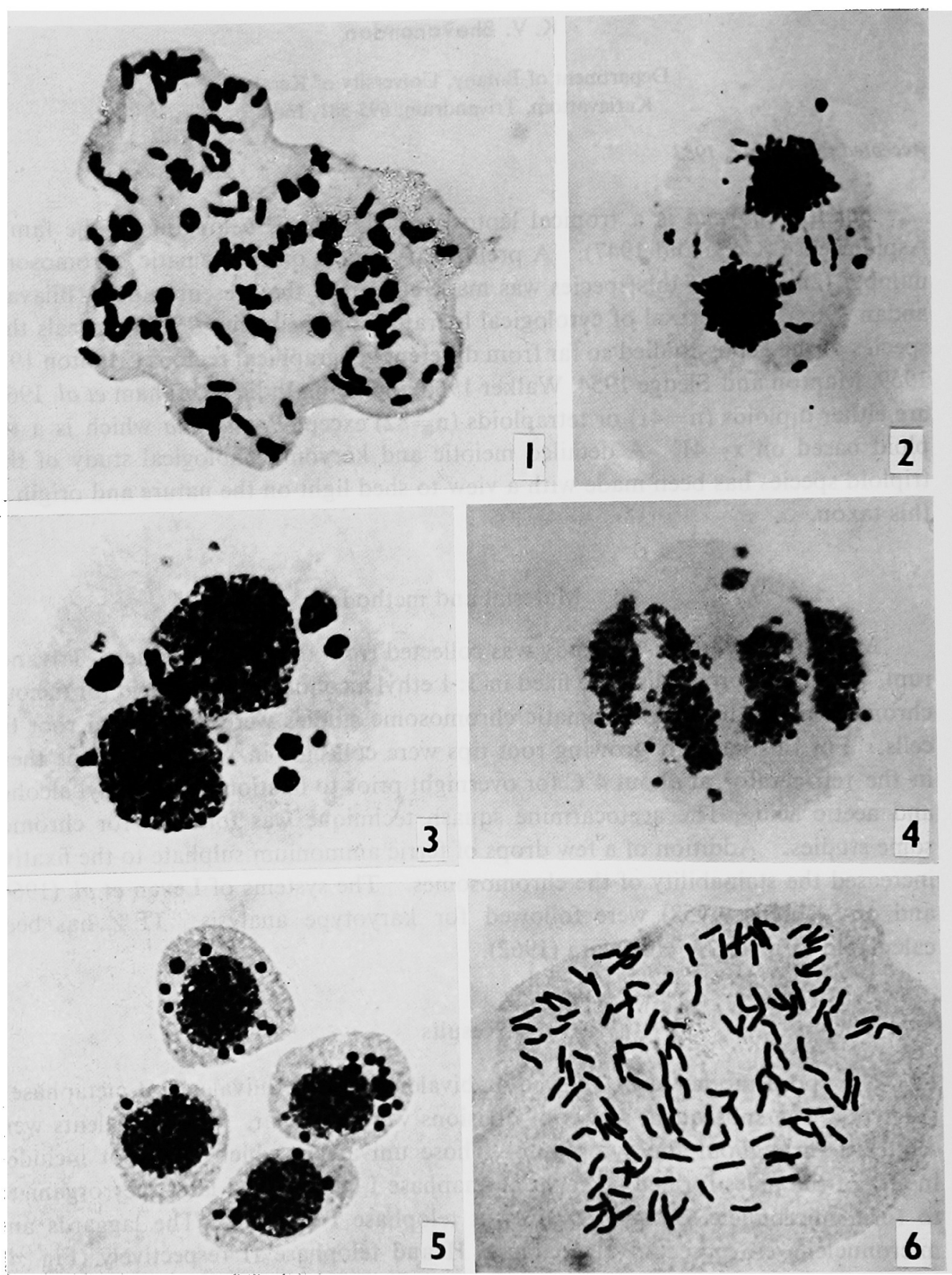

Figs. 1-6. Bolbitis quoyana. 1, a spore mother cell showing 41 bivalents and 41 univalents at metaphase I. 2, a spore mother cell showing laggards at late anaphase I. 3, micronuclei of varying sizes are seen in a spore mother cell at telophase I. 4, a spore mother cell showing micronuclei at telophase II. 5, tetrad with micronuclei. 6, a root tip cell showing 123 chromosomes at metaphase. All figs. $\times 760$. 
chromosomes it is found that the chromosomes in the complement could be grouped into two distinct sets, one diploid represented by 41 homologous pairs (AA) and the other, by 41 non-homologous (B) chromosomes (Fig. 7). The chromosome length in the A genome varied from $3.83 \mathrm{~m} \mu$ to $7 \mathrm{~m} \mu$ and it consisted of $3 \mathrm{~m}$ types, $7 \mathrm{sm}$ types, 14 st types and $17 \mathrm{t}$ types of chromosomes. The chromosomes of the $\mathrm{B}$

Table 1. Karyotype analysis of B. quoyana

\begin{tabular}{|c|c|c|c|c|c|c|c|}
\hline $\begin{array}{c}\text { Chromosome } \\
\text { No. }\end{array}$ & $\begin{array}{l}\text { Length of } \\
\text { short arm } \\
\qquad \operatorname{m} \mu\end{array}$ & $\begin{array}{l}\text { Length of } \\
\text { long arm } \\
\operatorname{m\mu } \mu\end{array}$ & $\begin{array}{l}\text { Total } \\
\text { length } \\
\mathrm{m} \mu\end{array}$ & $\begin{array}{l}\text { Arm } \\
\text { ratio } \\
\mathrm{L} / \mathrm{S}\end{array}$ & $\begin{array}{l}\text { Relative } \\
\text { length } \\
\text { m } \mu\end{array}$ & F \% & $\begin{array}{l}\text { Chromo- } \\
\text { some } \\
\text { designation }\end{array}$ \\
\hline \multicolumn{8}{|c|}{ Diploid A genome } \\
\hline 1 & 1.33 & 5.67 & 7.00 & 4.26 & 3.44 & 19 & st \\
\hline 2 & 1.42 & 5.00 & 6.42 & 3.52 & 3.15 & 22 & st \\
\hline 3 & 0.67 & 5.67 & 6.34 & 8.46 & 3.12 & 11 & $\mathrm{t}$ \\
\hline 4 & 1.00 & 5.33 & 6.33 & 5.33 & 3.11 & 15 & st \\
\hline 5 & 1.00 & 5.07 & 6.07 & 5.07 & 2.98 & 16 & st \\
\hline 6 & 2.00 & 4.00 & 6.00 & 2.00 & 2.94 & 33 & $\mathrm{sm}$ \\
\hline 7 & 1.67 & 4.33 & 6.00 & 2.59 & 2.94 & 27 & $\mathrm{sm}$ \\
\hline 8 & 0.33 & 5.67 & 6.00 & 17.18 & 2.94 & 5.5 & $t$ \\
\hline 9 & 0.33 & 5.5 & 5.83 & 16.67 & 2.86 & 5.6 & $\mathrm{t}$ \\
\hline 10 & 2.00 & 3.67 & 5.67 & 1.84 & 2.78 & 35 & $\mathrm{sm}$ \\
\hline 11 & 1.33 & 4.33 & 5.66 & 3.26 & 2.78 & 23 & st \\
\hline 12 & 1.33 & 4.33 & 5.66 & 3.26 & 2.78 & 23 & st \\
\hline 13 & 0.67 & 4.67 & 5.34 & 6.97 & 2.62 & 12 & st \\
\hline 14 & 0.67 & 4.67 & 5.34 & 6.97 & 2.62 & 12 & st \\
\hline 15 & 0.17 & 5.00 & 5.17 & 29.41 & 2.54 & 3.28 & $t$ \\
\hline 16 & 1.00 & 4.00 & 5.00 & 4.00 & 2.45 & 20 & st \\
\hline 17 & 0.67 & 4.33 & 5.00 & 6.46 & 2.45 & 13 & st \\
\hline 18 & 0.33 & 4.67 & 5.00 & 14.15 & 2.45 & 6.6 & $t$ \\
\hline 19 & 0.33 & 4.67 & 5.00 & 14.15 & 2.45 & 6.6 & $t$ \\
\hline 20 & 0.67 & 4.08 & 4.75 & 6.09 & 2.33 & 14 & $\mathrm{t}$ \\
\hline 21 & 0.58 & 4.17 & 4.75 & 7.19 & 2.33 & 12 & $t$ \\
\hline 22 & 2.00 & 2.67 & 4.67 & 1.34 & 2.29 & 42 & $\mathrm{sm}$ \\
\hline 23 & 2.00 & 2.67 & 4.67 & 1.34 & 2.29 & 42 & $\mathrm{sm}$ \\
\hline 24 & 0.67 & 4.00 & 4.67 & 5.97 & 2.29 & 14 & st \\
\hline 25 & 1.33 & 3.33 & 4.66 & 2.50 & 2.28 & 28 & $\mathrm{sm}$ \\
\hline 26 & 0.67 & 3.83 & 4.5 & 5.72 & 2.21 & 14 & st \\
\hline 27 & 0.44 & 4.00 & 4.44 & 9.09 & 2.18 & 9.9 & $t$ \\
\hline 28 & 0.33 & 4.1 & 4.43 & 12.42 & 2.17 & 7.4 & $\mathrm{t}$ \\
\hline 29 & 1.67 & 2.67 & 4.34 & 1.60 & 2.13 & 38 & $\mathrm{~m}$ \\
\hline 30 & 1.67 & 2.67 & 4.34 & 1.60 & 2.13 & 38 & $\mathrm{~m}$ \\
\hline 31 & 0.67 & 3.67 & 4.34 & 5.48 & 2.13 & 15 & st \\
\hline 32 & 0.33 & 4.00 & 4.33 & 12.12 & 2.12 & 7.6 & $t$ \\
\hline 33 & 0.33 & 4.00 & 4.33 & 12.12 & 2.12 & 7.6 & $t$ \\
\hline 34 & 0.33 & 4.00 & 4.33 & 12.12 & 2.12 & 7.6 & $t$ \\
\hline 35 & 1.5 & 2.67 & 4.16 & 1.78 & 2.04 & 36 & $\mathrm{sm}$ \\
\hline 36 & 0.33 & 3.67 & 4.00 & 11.12 & 1.96 & 8.25 & $\mathrm{t}$ \\
\hline 37 & 0.33 & 3.67 & 4.00 & 11.12 & 1.96 & 8.25 & $t$ \\
\hline 38 & 0.17 & 3.83 & 4.00 & 22.53 & 1.96 & 4.25 & $t$ \\
\hline 39 & 0.17 & 3.67 & 3.84 & 21.59 & 1.88 & 4.42 & $\mathrm{t}$ \\
\hline 40 & 1.83 & 2.00 & 3.83 & 1.09 & 1.88 & 47 & $\mathrm{~m}$ \\
\hline 41 & 0.33 & 3.5 & 3.83 & 10.61 & 1.88 & 8.6 & $t$ \\
\hline
\end{tabular}


Table 1. (continued)

\begin{tabular}{|c|c|c|c|c|c|c|c|}
\hline $\begin{array}{c}\text { Chromosome } \\
\text { no. }\end{array}$ & $\begin{array}{l}\text { Length of } \\
\text { short arm } \\
\quad \operatorname{m} \mu\end{array}$ & $\begin{array}{l}\text { Length of } \\
\text { long arm } \\
\mathrm{m} \mu\end{array}$ & $\begin{array}{l}\text { Total } \\
\text { length } \\
\mathrm{m} \mu\end{array}$ & $\begin{array}{l}\text { Arm } \\
\text { ratio } \\
\text { L/S }\end{array}$ & $\begin{array}{c}\text { Relative } \\
\text { length } \\
\mathrm{m} \mu\end{array}$ & F \% & $\begin{array}{l}\text { Chromo- } \\
\text { some } \\
\text { designation }\end{array}$ \\
\hline \multicolumn{8}{|c|}{ Haploid B genome } \\
\hline 1 & 0.67 & 6.33 & 7 & 9.45 & 3.38 & 9.57 & $\mathrm{t}$ \\
\hline 2 & 1.67 & 5.33 & 7 & 3.19 & 3.38 & 23 & st \\
\hline 3 & 1.53 & 5.33 & 6.83 & 3.48 & 3.30 & 24 & st \\
\hline 4 & 1.08 & 5.58 & 6.66 & 5.17 & 3.22 & 16 & st \\
\hline 5 & 1.75 & 4.42 & 6.27 & 2.53 & 3.03 & 27 & $\mathrm{sm}$ \\
\hline 6 & 1.17 & 4.67 & 5.84 & 3.99 & 2.82 & 20 & st \\
\hline 7 & 0.67 & 5.00 & 5.67 & 7.46 & 2.74 & 11 & $\mathbf{t}$ \\
\hline 8 & 1.08 & 4.5 & 5.58 & 4.17 & 2.69 & 19 & st \\
\hline 9 & 1.25 & 4.33 & 5.55 & 3.46 & 2.68 & 22 & st \\
\hline 10 & 0.33 & 5.17 & 5.5 & 15.67 & 2.66 & 6.00 & $\mathrm{t}$ \\
\hline 11 & 0.17 & 5.33 & 5.5 & 31.35 & 2.66 & 3.09 & $t$ \\
\hline 12 & 1.00 & 4.33 & 5.33 & 4.33 & 2.57 & 18 & st \\
\hline 13 & 2.25 & 3.00 & 5.25 & 1.33 & 2.53 & 42 & $\mathrm{~m}$ \\
\hline 14 & 0.75 & 4.5 & 5.25 & 6.00 & 2.53 & 14 & st \\
\hline 15 & 1.17 & 4.00 & 5.17 & 3.42 & 2.50 & 22 & st \\
\hline 16 & 0.5 & 4.60 & 5.17 & 9.34 & 2.50 & 9.67 & $t$ \\
\hline 17 & 1.42 & 3.67 & 5.09 & 2.58 & 2.46 & 19 & $\mathrm{sm}$ \\
\hline 18 & 2.00 & 3.00 & 5.00 & 1.5 & 2.41 & 40 & $\mathrm{sm}$ \\
\hline 19 & 1.50 & 3.50 & 5.00 & 2.33 & 2.41 & 30 & sm \\
\hline 20 & 1.33 & 3.67 & 5.00 & 2.76 & 2.41 & 36 & sm \\
\hline 21 & 0.17 & 4.83 & 5.00 & 28.41 & 2.41 & 3.40 & $t$ \\
\hline 22 & 0.33 & 4.58 & 4.91 & 13.87 & 2.37 & 6.72 & $t$ \\
\hline 23 & 1.44 & 3.4 & 4.84 & 2.36 & 2.34 & 29 & $\mathrm{sm}$ \\
\hline 24 & 1.17 & 3.67 & 4.84 & 3.13 & 2.34 & 21 & st \\
\hline 25 & 0.84 & 4.00 & 4.84 & 4.76 & 2.34 & 17 & st \\
\hline 26 & 0.17 & 4.67 & 4.84 & 27.47 & 2.34 & 21 & $t$ \\
\hline 27 & 1.75 & 3.00 & 4.75 & 1.71 & 2.29 & 36 & $\mathrm{sm}$ \\
\hline 28 & 0.25 & 4.42 & 4.67 & 17.68 & 2.25 & 5.35 & $t$ \\
\hline 29 & 0.33 & 4.33 & 4.66 & 13.12 & 2.25 & 7.08 & $t$ \\
\hline 30 & 1.5 & 3.08 & 4.58 & 2.05 & 2.21 & 32 & $\mathrm{sm}$ \\
\hline 31 & 2.00 & 2.5 & 4.5 & 1.25 & 2.17 & 44 & $\mathrm{sm}$ \\
\hline 32 & 1.17 & 3.33 & 4.5 & 2.85 & 2.17 & 26 & $\mathrm{sm}$ \\
\hline 33 & 1.00 & 3.5 & 4.5 & 3.5 & 2.17 & 22 & st \\
\hline 34 & 0.67 & 3.83 & 4.5 & 5.72 & 2.17 & 14 & st \\
\hline 35 & 0.33 & 4.17 & 4.5 & 12.64 & 2.17 & 7.33 & $t$ \\
\hline 36 & 0.92 & 3.42 & 4.34 & 3.71 & 2.09 & 21 & st \\
\hline 37 & 0.25 & 4.08 & 4.33 & 16.32 & 2.09 & 5.77 & $t$ \\
\hline 38 & 1.08 & 3.08 & 4.16 & 2.85 & 2.01 & 25 & $\mathrm{sm}$ \\
\hline 39 & 0.33 & 3.62 & 3.95 & 10.9 & 1.91 & 8.35 & $t$ \\
\hline 40 & 1.00 & 2.92 & 3.92 & 2.92 & 1.89 & 25 & $\mathrm{sm}$ \\
\hline 41 & 0.17 & 3.33 & 3.5 & 19.59 & 1.69 & 4.85 & $t$ \\
\hline
\end{tabular}

genome varied in length from $3.5 \mathrm{~m} \mu$ to $7 \mathrm{~m} \mu$, and it consisted of $1 \mathrm{~m}$ type, $11 \mathrm{sm}$ types, 14 st types and $15 \mathrm{t}$ types of chromosomes. However, both the genomes are almost similar with regard to TCL, TSL, range of $\mathrm{F} \%$ and $\mathrm{TF}_{\circ} \circ$ (Table 2). It has been found that 33 chromosomes $(85 \%)$ in the A genome and 37 chromosomes 
$(90.2 \%)$ in the $\mathrm{B}$ genome have the arm ratio more than two. It has been observed that both the $\mathrm{A}$ and $\mathrm{B}$ genomes are asymmetric and come under $3 \mathrm{~A}$ and $3 \mathrm{~B}$ category respectively.
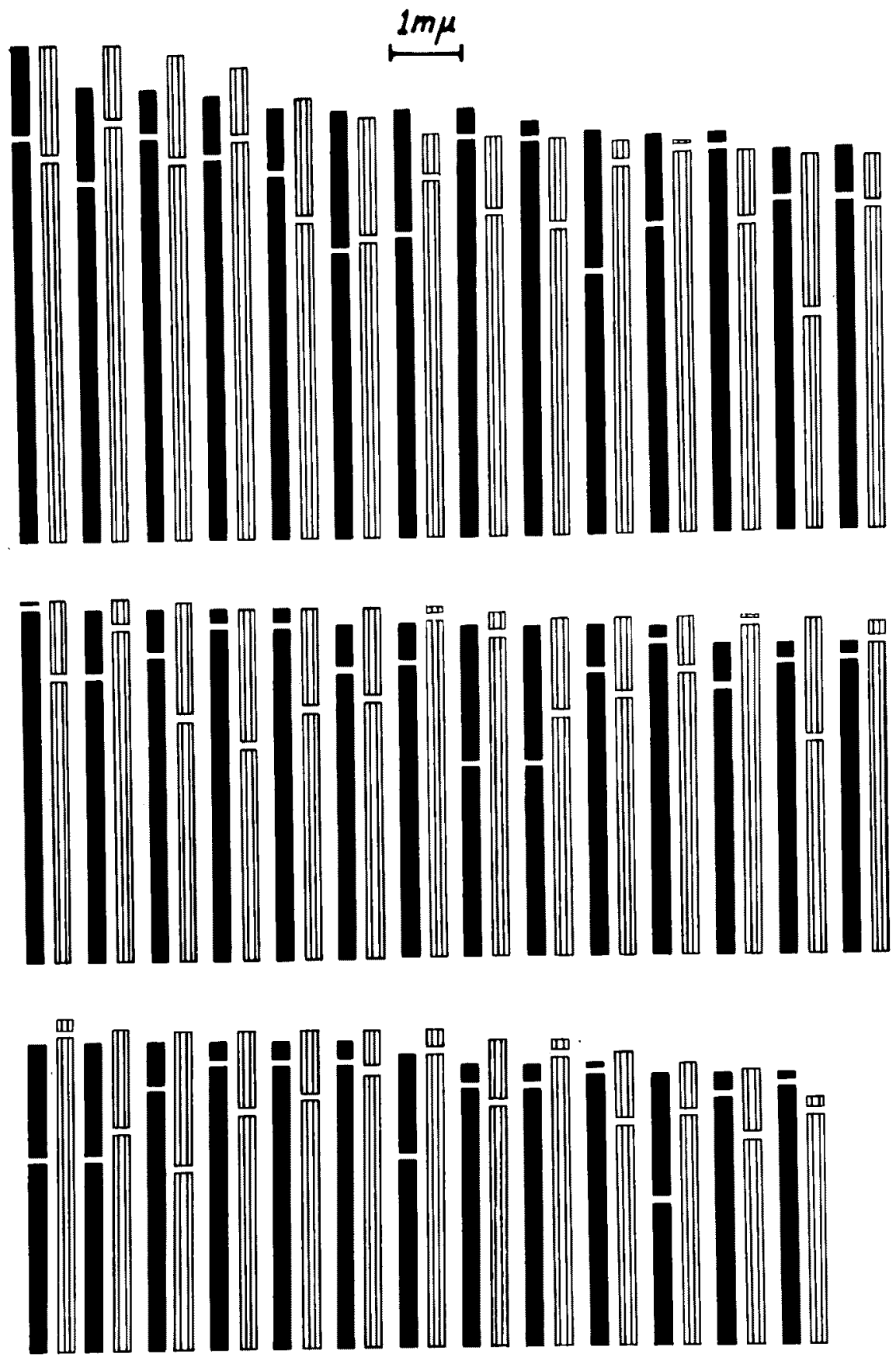

- A genome Ill B genome

Fig. 7. Idiogram of Bolbitis quoyana. 


\section{Discussion}

The meiosis in this taxon is characterized by the formation of 41 bivalents and 41 univalents. This appears to indicate that the somatic complement of this material is composed of two different genomes, one of which is diploid consisting of 41 homologous pairs (A genome) and the other with 41 non-homologous chromosomes (B genome). Further, the total absence of trivalents or higher associations at meiosis may be considered to indicate that there is apparently no homology between the chromosomes of the $\mathrm{A}$ and $\mathrm{B}$ genomes of the taxon.

Table 2. Summary of karyomorphological data of B. quoyana

\begin{tabular}{|c|c|c|c|c|c|c|c|c|c|c|c|}
\hline \multirow[t]{2}{*}{$\begin{array}{l}\text { Name of } \\
\text { genomes }\end{array}$} & \multirow[t]{2}{*}{$\begin{array}{l}\text { Number } \\
\text { of chro- } \\
\text { mosomes } \\
\text { (hap- } \\
\text { loid set)- }\end{array}$} & \multicolumn{4}{|c|}{$\begin{array}{l}\text { Number of } \\
\text { chromosomes } \\
\text { according to } \\
\text { centromere } \\
\text { position }\end{array}$} & \multirow[t]{2}{*}{$\begin{array}{l}\text { Range } \\
\text { of chro- } \\
\text { mosome } \\
\text { length } \\
\text { in } \mathrm{m} \mu\end{array}$} & \multirow[t]{2}{*}{$\begin{array}{c}\text { Total } \\
\text { chromo- } \\
\text { some } \\
\text { length } \\
\text { (TCL) } \\
\text { m } \mu\end{array}$} & \multirow[t]{2}{*}{$\begin{array}{c}\text { Total } \\
\text { short } \\
\text { arm } \\
\text { length } \\
\text { (TSL) } \\
\text { m } \mu\end{array}$} & \multirow[t]{2}{*}{$\begin{array}{l}\text { Range } \\
\text { of } F \%\end{array}$} & \multirow[t]{2}{*}{ TF $\%$} & \multirow[t]{2}{*}{$\begin{array}{l}\text { Karyo- } \\
\text { type } \\
\text { asym- } \\
\text { metry }\end{array}$} \\
\hline & & $\mathrm{m}$ & $\mathrm{sm}$ & st & $\mathbf{t}$ & & & & & & \\
\hline A & 41 & 3 & 7 & 14 & 17 & $\begin{array}{l}3.83 \\
\text { to } 7\end{array}$ & 203.51 & 36.6 & $\begin{array}{r}3.28 \\
\text { to } 47\end{array}$ & 17.98 & $3 \mathrm{~A}$ \\
\hline B & 41 & 1 & 11 & 14 & 15 & $\begin{array}{l}3.5 \\
\text { to } 7\end{array}$ & 206.7 & 39.5 & $\begin{array}{r}3.09 \\
\text { to } 44\end{array}$ & 19.13 & 3 B \\
\hline
\end{tabular}

$\mathrm{TCL}=$ Total chromosome length

$\mathrm{F} \%=\frac{\text { Short arm length }}{\text { Chromosome length }} \times 100$
TSL $=$ Total short arm length

$\mathrm{TF} \%=\frac{\text { Total sum of short arm length }}{\text { Total sum of chromosome length }} \times 100$

Evidence from karyotype analysis shows that, the somatic complement of the taxon could be divided into two groups such as a diploid set of 41 pairs of chromosomes and a haploid set of 41 chromosomes. It may be noted that the chromosome belonging to the two sets showed no recognizable homology. This together with the type of meiotic behaviour observed appears to indicate that the taxon possesses an allotriploid constitution originated from two different species. A condition like this can arise spontaneously either by crossing between two species, one of which is a tetraploid and the other a diploid or by fusion between the unreduced gamete ( $2 n)$ of a diploid species and a normal gamete (n) of yet another diploid species. It may be noted that, so far no tetraploid species of Bolbitis has been reported from India and hence the latter possibility appears to be more plausible for origin of the present triploid taxon.

\section{Summary}

Detailed cytological study of $B$. quoyana $(2 n=123)$ was made. Regular formation of 41 bivalents and 41 univalents was consistantly noticed in the spore mother cells.

Detailed karyomorphology of the material was studied and the data indicated that the karyotype is composed of two distinct sets, a diploid one consisting of 41 pairs, and a haploid set consisting of 41 non-homologous chromosomes.

The result appeared to indicate that this is an allotriploid species possibly ori- 
ginated spontaneously by the fusion between the unreduced (2n) and normal (n) gametes of two diploid species of Bolbitis.

\section{Acknowledgement}

The author is deeply indebted to Dr. C. A. Ninan, Professor and Head of the Department of Botany, University of Kerala, Kariavattom, Trivandrum for the necessary laboratory facilities and encouragements.

\section{References}

Abraham, A., Ninan, C. A. and Mathew, P. M. 1962. Studies on the cytology and phylogeny of the pteridophytes. VII. Observations on one hundred species of South Indian ferns. Jour. Ind. Bot. Soc. 41 : 339-421.

Bhavanandan, K. V. 1968. Studies on the cytology of sixteen species of South Indian ferns. Caryologia 21 : 333-338.

Copeland, E. B. 1947. Genera Filicum. Waltham, Mass. Chronica, Botanica Co.

Huziwara, Y. 1962. Karyotype analysis in some genera of Compositae. VIII. Further studies on the chromosome of aster. Amer. J. Bot. 49: 116-119.

Levan, A., Fredga, K. and Sandberg, A. A. 1964. Nomenclature for centromere position on chromosomes. Hereditas 52: 201-220.

Manton, I. 1954. Cytological notes on one hundred species of Malayan ferns. Appendix to "Flora of Malaya". Vol. II. Ferns. Holttum. Govt. Press, Singapore.

- 1959. Cytological information on the ferns of West Tropical Africa. In Alston pp. 75-81. Crow Agents for Overseas Governments and Administrations, London.

— and Sledge, W. A. 1954. Observations on the cytology and taxonomy of the pteridophyte flora of Ceylon. Phil. Trans. Roy. Soc. Lond. Series B. Biol. Sci. 238: 127-185.

Stebbins, G. L. Jr. 1958. Longivity, habitat and release of genetic variability in higher plants. Cold Spring Harb. Symp. Quant. Biol. 23: 365-378.

Walker, T. G. 1966. A cytotaxonomic survey of the pteridophytes of Jamaica. Trans. Roy. Soc. Eding. 66 (9): 169-237. 